\title{
Species diversity and composition of mangroves in Tacloban City, Philippines
}

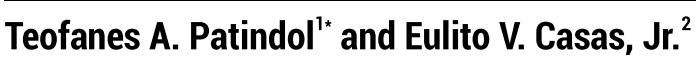

\begin{abstract}
This study reflects the present status of Tacloban City mangrove vegetation and would be useful for mangrove restoration program. Surveys of mangrove forests in Tacloban City were conducted from October to November 2017 in 12 selected sites. Quadrat method was used to assess the species composition and stand structure of the canopy layer, representing seaward, middle and landward zones. The mangrove forests in Tacloban City contain 23 mangrove species belonging to 12 families and 15 genera. Rhizophoraceae and Acanthaceae are the most dominating families. As per IUCN report, among the 23 species, 4 were recognized as threatened. These include the Endangered Camptostemon philippinensis, the Vulnerable Avicennia rumpiana and the Near Threatened Aegiceras floridum and Ceriops decandra. Rhizophora apiculata is the most abundant species, followed by Sonneratia alba. Other abundant species are Avicennia officinalis, Avicennia marina and Rhizophora mucronata. The least abundant are Bruguiera gymnorrhiza, Camptostemon philippinensis and Xylocarpus granatum. The canopy layer is composed of small-sized trees with an average tree density of 1,678 per ha and stem density of 3,133 per ha. The average height and diameter are $6.15 \mathrm{~m}$ and $8.95 \mathrm{~cm}$, respectively. Mangrove diversity is generally low. Shannon index of diversity value ranges from 0.762 to 1.132 , with an average value of 0.914 . Understory is characterized by few species of regenerants, low density and low species diversity.
\end{abstract}

Keywords: mangroves, composition, species diversity, Tacloban City, Philippines

\section{INTRODUCTION}

Mangroves are virtually confined to the tropics. They often form a dense intertidal forest that dominates muddy intertidal shores, frequently consisting of

Department of Forest Science, College of Forestry and Environmental Science, Visayas State University, Baybay City, Leyte

${ }^{2}$ Division of Natural Sciences and Mathematics, University of the Philippines Visayas-Tacloban College, Tacloban City

*Corresponding Author. Address: Department of Forest Science, College of Forestry and Environmental Science, Visayas State University, Baybay City, Leyte;Email: tapatindol@yahoo.com 
virtually monospecific patches or bands (Hogarth 2015). Mangroves form unique ecological environments which provide an appropriate habitat for a rich assemblage of species. Aside from its ecological function, mangroves representatives such as Rhizophora spp., function as a physical barrier against sea surges using their large aerial root systems and props.

Mangroves have been recognized as a primary line of defense against coastal perturbations such as typhoons, tsunamis, and storm surges. The catastrophic impacts and extent of calamity of Typhoon Yolanda in the Philippines during November 2013, has triggered the need for rehabilitation and restoration of mangrove ecosystems in Tacloban City. Such effort must be geared towards the preservation of the ecological functions of mangrove ecosystems and improvement of the economic condition of the people living in coastal areas, through sustainable livelihood activities.

A proper quantitative information of the existing mangrove resources is necessary before undertaking a well-planned restoration program, which is lacking in Tacloban City, Philippines. Thus, prior to formulating the restoration program, a scientific survey is necessary to understand the existing contribution of the mangrove resources in Tacloban City. Assessment of the current status of mangrove resources (comprising the remnant mangrove forests) within Tacloban City can provide baseline data in order to measure the intended project benefits, specifically on biodiversity, as a result of the intervention in the future. In a broader perspective, the result of this study would serve as valuable input in formulating integrated conservation strategies that would promote biodiversity conservation and at the same time, address the economic needs of the vulnerable coastal communities in the context of participatory resource management.

\section{METHODOLOGY}

The study was conducted in 12 selected mangrove forests within the different barangays in Tacloban City (Figure 1). The study sites are located in Tagpuro, Old Kawayan, San Isidro, Cabalawan, Bagacay, Anibong and San Jose.

Quadrat method (BMB 2017) was used to assess the mangrove forests in Tacloban City. Three quadrats measuring $10 \mathrm{~m} \times 10 \mathrm{~m}$ were laid out to represent the seaward zone, middle zone and landward zone in each of the sample sites. Sampling areas were strategically located to represent different sites of species composition along the mangrove coastal areas. All trees inside the $10 \mathrm{~m} \times 10 \mathrm{~m}$ quadrat, with diameter of equal or greater than $5 \mathrm{~cm}$, were identified and measured for diameter at breast height (DBH) and total height (TH). While small trees $(<5 \mathrm{~cm}$ $\mathrm{DBH}$ ) and other non-tree flora (shrubs, vines, herbs, ferns) were identified and counted inside the $2 \mathrm{~m} \times 2 \mathrm{~m}$ quadrat. 
Species diversity and composition of mangroves

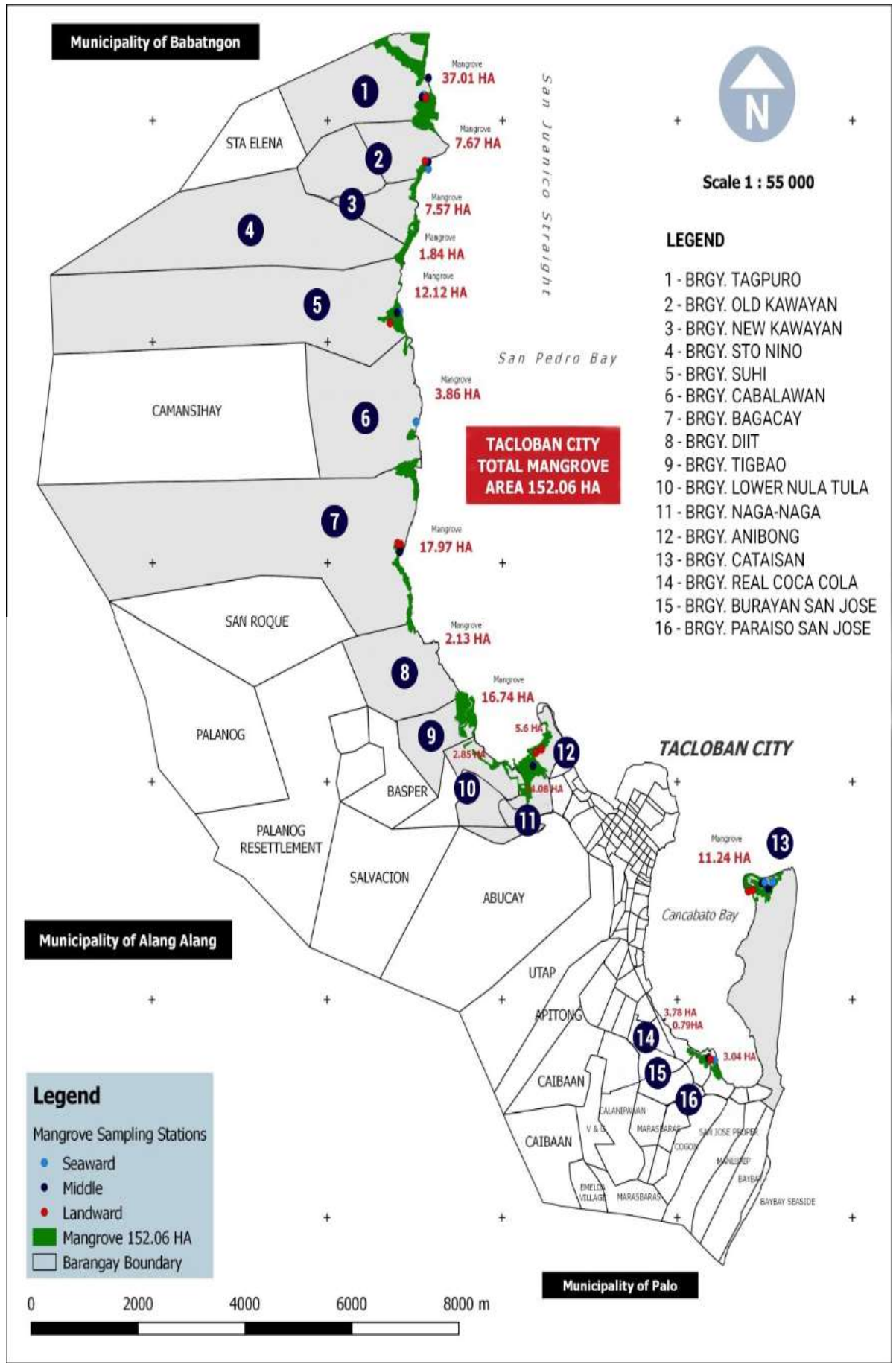

Figure 1. Map of Tacloban City showing the different mangrove sampling stations.

Data Source: Mangrove Mark Lama 2017, based on the Google Satellite Image. Sampling stations - Dr. T. Patindol. 
Vegetation structure was described using tree density, stem density, tree diameter, DBH $(\mathrm{cm})$ and tree height $(\mathrm{m})$. Identification of species was done according to the description of Primavera (2009). Species diversity was determined using the Shannon index of diversity, with the formula for the computation based on Magurran (1988):

$$
H^{\prime}=-\sum\left[\frac{\mathrm{n} 1}{\mathrm{n}}\right]\left[\ln \frac{\mathrm{n} 1}{\mathrm{n}}\right]
$$

where:

$$
\begin{aligned}
& H^{\prime}=\text { Shannon index of diversity } \\
& n 1=\text { frequency of occurrence of species within the } 125 \text { plots } \\
& n=\text { the total number of occurrences of all species in all plots. }
\end{aligned}
$$

Numerical abundance and relative abundance for every species encountered both in the canopy layer and understory layer were determined. Numerical abundance was determined by simply counting the number of individuals of a species that appeared in all plots while relative abundance was determined by counting the number of plots that a species was encountered, regardless of the number of individuals.

\section{RESULTS AND DISCUSSION}

\section{Species Composition}

A total of 23 mangrove species were recorded in Tacloban City (Table 1). These species comprise about $70 \%$ of the total number of mangrove species recorded in the country (Garcia et al 2014). These species belong to 12 families and 15 genera. Rhizophoraceae is the most represented family with seven species, followed by Acanthaceae with four species. Species belonging to Rhizophoraceae include Rhizophora mucronata, Rhizophora stylosa, Rhizophora apiculata, Bruguiera gymnorrhiza, Bruguiera cylindrica, Ceriops decandra and Ceriops tagal, while those of Acanthaceae includes Avicennia marina, Avicennia officinalis and Avicennia rumpiana.

The conservation status of the species appeared online in the IUCN Red List Category of Species. Of the 23 species recognized by IUCN, 1 is considered Endangered (E), 1 Vulnerable (VU) and 2 Near Threatened (NT). The Endangered species is Camptostemon philippinensis (Plate 1), while the Vulnerable species is Avicennia rumpiana (Plate 2). The Near Threatened species are Aegiceras floridum (Plate 3) and Ceriops decandra (Plate 4). 
Species diversity and composition of mangroves

Table 1. Mangrove species composition in Tacloban City, c. 2017

\begin{tabular}{llll}
\hline \multicolumn{1}{c}{ Family } & \multicolumn{1}{c}{ Scientific Name } & \multicolumn{1}{c}{ Common Name } & Conservation Status \\
\hline Acanthaceae & Acanthus ebracteatus & Lagiwliw & Least Concern \\
Acanthaceae & Avicennia marina & Bungalon & Least Concern \\
Acanthaceae & Avicennia officinalis & Api-api & Least Concern \\
Acanthaceae & Avicennia rumpiana & Miapi & Vulnerable \\
Arecaceae & Nypa fruticans & Nipa & Least Concern \\
Bombacaceae & Camptostemon philippinensis & Gapas-gapas & Endangered \\
Combretaceae & Lumnitzera littorea & Tabao & Least Concern \\
Euphorbiaceae & Excoecaria agallocha & Lipata & Least Concern \\
Meliaceae & Xylocarpus granatum & Tabigi & Least Concern \\
Meliaceae & Xylocarpus moluccensis & Piag-ao & Least Concern \\
Myrsinaceae & Aegiceras corniculatum & Saging-saging & Least Concern \\
Myrsinaceae & Aegiceras floridum & Tinduk-tindukan & Near Threatened \\
Myrtaceae & Osbornia octodonta & Tawalis & Least Concern \\
Pteridaceae & Acrostichum speciosum & Palaypay & Least Concern \\
Rhizophoraceae & Bruguiera gymnorrhiza & Busain & Least Concern \\
Rhizophoraceae & Bruguiera cylindrica & Pototan & Least Concern \\
Rhizophoraceae & Ceriops decandra & Malatangal & Near Threatened \\
Rhizophoraceae & Ceriops tagal & Tangal & Least Concern \\
Rhizophoraceae & Rhizophora apiculata & Bakauan lalaki & Least Concern \\
Rhizophoraceae & Rhizophora mucronata & Bakauan babae & Least Concern \\
Rhizophoraceae & Rhizophora stylosa & Bakauan bato & Least Concern \\
Sonneratiaceae & Sonneratia alba & Pagatpat & Least Concern \\
Sterculiceae & Heritiera littoralis & Dungon late & Least Concern \\
\hline
\end{tabular}

Abundance and Distribution

Overall total of 604 individuals of true mangroves were recorded from the 12 sapling sites (Table 2). R. apiculata (Plate 1) is the most abundant, having the highest number of individuals (222). S. alba is the second most abundant (Plate 2) with 143 individuals. The next most abundant are A. officinalis, $A$. marina and $R$. mucronata, while the least abundant are B. gymnorrhiza, $C$. philippinensis and $X$. granatum.

Two species ( $R$. apiculata \& S. alba) were observed to occur in all sampling sites. One species (Avicennia officinalis) appeared in seven sites, while another two species (A. marina \& $R$. mucronata) occurred in six sites. Six species (R. stylosa, $X$. moluccensis, A. floridum, B. gymnorrhiza, C. philippinensis \& X. granatum) occurred in a single site only. The result shows that the abundant species are also widely distributed species, while the less abundant species are those with limited distribution. 
Patindol \& Casas

Table 2. Distribution and abundance of mangroves in Tacloban City, c. 2017

\begin{tabular}{lllll}
\hline \multicolumn{1}{c}{ Scientific Name } & Common Name & Abundance & Relative Frequency \\
\hline Rhizophora apiculata & Bakauan lalaki & 222 & 12 \\
Sonneratia alba & Pagatpat & 143 & 12 \\
Avicennia officinalis & Api-api & 48 & 7 \\
Avicennia marina & Bungalon & 39 & 6 \\
Rhizophora mucronata & Bakauan babae & 29 & 6 \\
Excoecaria agallocha & Lipata & 25 & 5 \\
Avicenia rumpiana & Miapi & 32 & 4 \\
Lumnitzera littorea & Tabao & 9 & 4 \\
Ceriops decandra & Malatangal & 9 & 4 \\
Osbornia octodonta & Tawalis & 5 & 3 \\
Heritiera littoralis & Dungon late & 5 & 3 \\
Aegiceras corniculatum & Saging-saging & 12 & 2 \\
Bruguiera cylindrica & Pototan & 7 & 2 \\
Ceriops tagal & Tangal & 5 & 2 \\
Rhizophora stylosa & Bakauan bato & 7 & 1 \\
Xylocarpus moluccensis & Piag-ao & 2 & 1 \\
Aegiceras floridum & Tinduk-tindukan & 2 & 1 \\
Bruguiera gymnorrhiza & Busain & 1 & 1 \\
Camptostemon philippinensis & Gapas-gapas & 1 & 1 \\
Xylocarpus granatum & Tabigi & 1 & 1 \\
\hline AbundanceNmal Abundancin & sampling & & \\
\hline
\end{tabular}

Abundance=Numerical Abundance in 12 sampling sites Relative frequency=0ccurrence in 12 sampling sites

$R$. apiculata is generally widespread throughout the mangrove swamp, although it prefers soft mud normally flooded by tidal water. $R$. mucronata usually occurs along tidal streams and, river banks with soils rich in humus. A. marina is abundant in exposed areas facing the sea and has high tolerance to hyper saline conditions. A. officinalis sporadically occurs on river banks on firm mud and rare on the seaward zone. S. alba usually occurs in newly formed sandy mudflats in estuaries and tidal streams and can tolerate salinity (Melana \& Gonzales 2000). It is important to note that these five widespread and most abundant species have enough potential for mangrove reforestation in Tacoban City. $R$. apiculata can be planted in all zones within the mangrove swamp. A. marina and $S$. alba are best recommended for seaward zone, while $R$. mucronata and $A$. officinalis can be planted along river banks or on zones away from the sea.

Among the five species of limited distribution, and at the same time very low abundance, are the Endangered $C$. philippinensis and the Near Threatened $A$. floridum (according to IUCN Redlist Categories) have been traced out in this part of the region. This indicates that restoration and rehabilitation of mangrove ecosystems in Tacloban City is a mere responsibility for the protection 
Species diversity and composition of mangroves

of these species, along with the other threatened species like the Vulnerable $A$. rumpiana and Near Threatened C. decandra.

\section{Stand Structure and Species Diversity}

The stand structure of mangroves in Tacloban City is shown in Table 3 . The canopy layer was composed of small-sized trees with an average tree density of 1,678 per ha and stem density of 3,133 per ha. Highest tree density was observed in the seaward zone while the lowest was observed in the landward zone. The same trend was observed for the stem density. The average total height was $6.15 \mathrm{~m}$ and average diameter was $8.95 \mathrm{~cm}$. In terms of tree height and tree diameter, the seaward zone had the lowest values while the landward zone had the largest values.

Table 3. Mangrove vegetation structure in Tacloban City, c. 2017

\begin{tabular}{lllll}
\hline & Seaward & Middle & Landward & Mean \\
\hline Tree Density per Hectare & 2,025 & 1,525 & 1,483 & 1,678 \\
Stem Density per Hectare & 3,850 & 3,050 & 2,500 & 3,133 \\
Tree Diameter DBH $(\mathrm{cm})$ & 8.01 & 8.11 & 10.72 & 8.95 \\
Tree Height $(\mathrm{m})$ & 4.77 & 5.93 & 7.75 & 6.15 \\
Index of Diversity $\left(\mathrm{H}^{\prime}\right)$ & 0.84 & 0.76 & 1.13 & 0.91 \\
Number of Species per plot & 3.17 & 3.08 & 4.33 & 3.53 \\
\hline
\end{tabular}

Generally, the seaward zone is characterized by high tree and stem densities but composed of small-diameter and short trees. Such condition must have resulted from the long history of cutting of mangroves so that what remain today are mostly multi-stem Avicennia and Sonneratia that must have regenerated after heavy cutting in the past years. The landward zones, especially the less accessible sites from the inland side, are generally protected for years as evidenced by the lowdensity stand which is composed mainly of big-diameter trees.

Mangrove diversity is generally low. Shannon index of diversity value ranges from 0.762 to 1.132 with an average value of 0.914 , which is considered very low based on the classification postulated by Fernando et al (BMB 2017). Low diversity is attributed to the few number of species and the uneven distribution of individuals among the different species. Number of individuals per species is extremely high for the most dominant species. Number of species is low, with an average of 3.53 per plot. Highest value for both species diversity and number of species were observed in the landward zone, followed by the seaward zone. Lowest values were observed in the middle layer. Higher values in the landward zone could be attributed to its inherent proximity to the land-based community that allows integration of species from both adjoining communities. On the other hand, the higher value in the seaward zone could be attributed to the disturbance regime from both man-made and natural forces.

\section{Frequency and Abundance of Mangrove Regenerants}

A total of 17 species of mangroves were encountered in the understory as regenerants (Table 4). The most frequently occurring and most abundant species in 
the understory layer was $R$. apiculata, followed by $A$. corniculatum. Only three other species showed higher occurrence and abundance. These were A. marina, $R$. mucronata, and C. decandra.

Table 4. Distribution and abundance of mangrove regenerants in Tacloban City, c. 2017

\begin{tabular}{llcc}
\hline Scientific Name & Common Name & Abundance & Relative Frequency \\
\hline Rhizophora apiculata & Bakauan lalaki & 223 & 9 \\
Aegiceras corniculatum & Saging-saging & 192 & 7 \\
Avicennia marina & Bungalon & 112 & 4 \\
Rhizophora mucronata & Bakauan babae & 45 & 4 \\
Ceriops decandra & Malatangal & 31 & 4 \\
Avicennia officinalis & Api-api & 40 & 3 \\
Bruguiera cylindrical & Pototan & 24 & 3 \\
Ceriops tagal & Tangal & 31 & 2 \\
Aegiceras floridum & Tinduk-tindukan & 28 & 2 \\
Osbornia octodonta & Tawalis & 8 & 2 \\
Heritiera littoralis & Dungon late & 5 & 2 \\
Lumnitzera littorea & Tabao & 5 & 2 \\
Avicennia rumpiana & Miapi & 9 & 1 \\
Rhizophora stylosa & Bakauan bato & 9 & 1 \\
Sonneratia alba & Pagatpat & 6 & 1 \\
Xylocarpus moluccensis & Piag-ao & 3 & 1 \\
Bruguiera gymnorrhiza & Busain & 3 & 1 \\
\hline
\end{tabular}

Abundance=Numerical Abundance in 12 sampling sites Relative frequency=0ccurrence in 12 sampling sites

Understory is characterized by few species of regenerants, low density and low species diversity (Table 5). The average number of species per plot was 2.39 with a density of 7.22 individuals per sq. meter. The index of diversity was very low at 0.595 . Highest values were observed in the landward zone while lowest values were observed in the seaward zone.

Table 5. Species diversity and density of mangrove regenerants in Tacloban City, c. 2017

\begin{tabular}{lllll}
\hline & Seaward & Middle & Landward & Mean \\
\hline Number of species per plot & 1.83 & 1.83 & 3.50 & 2.39 \\
Density per $\mathrm{m}^{2}$ & 5.23 & 5.44 & 10.98 & 7.22 \\
Index of Diversity $\left(\mathrm{H}^{\prime}\right)$ & 0.458 & 0.468 & 0.860 & 0.595 \\
\hline
\end{tabular}

The results showed that the understory contains very few regenerants. Thus, rehabilitation of the mangrove stands in Tacloban City would take time if only rely on the natural regeneration process. There is, therefore, a need to initiate a more comprehensive program on mangrove rehabilitation to consider speeding up the natural regeneration process and at the same time, address both anthropogenic and natural disturbances. 
Species diversity and composition of mangroves

\section{CONCLUSION}

Based on the result of the study, the following conclusions are drawn:

1. The mangrove forests in Tacloban City contain a total of 23 mangrove species belonging to 12 families and 15 genera. Rhizophoraceae and Acanthaceae were the most represented families.

2. Of the 23 species, four were recognized by IUCN as threatened. These include the Endangered Camptostemon philippinensis, the Vulnerable Avicennia rumpiana and the Near Threatened Aegiceras floridum and Ceriops decandra.

3. Rhizophora apiculata was the most predominant species followed by Sonneratia alba. Other abundant species were Avicennia officinalis, Avicennia marina and Rhizophora mucronata. The least abundant were Bruguiera gymnorrhiza, Camptostemon philippinensis and Xylocarpus granatum

4. The canopy layer was composed of small-sized trees with an average tree density of 1,678 and stem density of 3,133 per ha. The average total height was $6.15 \mathrm{~m}$ and average diameter was $8.95 \mathrm{~cm}$.

5. Mangrove species diversity was generally low. Shannon index of diversity value ranges from 0.762 to 1.132 with an average value of 0.914 .

6. Understory was characterized by few species of regenerants, low density and low species diversity.

\section{REFERENCES}

Biodiversity Management Bureau (BMB). 2017. Terrestrial Ecosystems Biodiversity and Assessment Monitoring Manual (pp1-136)

Garcia K, Malabrigo P \& Gevaña D. 2014. Philippines' Mangrove Ecosystem: Status, Threats and Conservation. In Faridah-Hanum I, Latiff A, Hakeem K \& Ozturk M (eds) Mangrove Ecosystems of Asia. Springer, New York

Hogarth PJ. 2015. The biology of mangroves and seagrasses (3rd edn) (pp1-304). Oxford University Press

Magurran AE. 1988. Ecological Diversity and Its Measurement (pp179). Princeton University Press, Princeton, New Jersey

Melana EE and Gonzales HI. 1996. Field guide to the identification of some mangrove plant species in the Philippines. Department of Environment and Natural Resources, Philippines

Primavera JH. 2009. Field Guide to Philippine Mangroves 